\title{
UPAYA MENINGKATKAN HASIL BELAJAR EKONOMI MELALUI PEMBELAJARAN KOOPERATIF TIPE NUMBERED HEAD TOGETHER (NHT) PADA SMA NEGERI 4 PALANGKA RAYA
}

\author{
Oleh \\ Minggus Harriyanto, ${ }^{*}$ Endang Sri Suyati**
}

\begin{abstract}
This study aims to find out the learning activities and increase the learning outcomes of students in class XI-8 on Economic subjects using the NHT type cooperative learning model. The method used in this study is Classroom Action Research (CAR). The subjects in this study were all students of class XI-8, amounting to 37 people at SMAN 4 Palangka Raya. Data collection techniques needed in this study are Observation, Documentation and Test. The data analysis technique used is qualitative and quantitative. The results of the study concluded that: (1) Learning activities of students became more active. This is evidenced by the response of students to a more vibrant learning process, so that it can be said that the Numbered Head Together (NHT) learning model is effective for improving economic learning outcomes, (2) There is an increase in learning outcomes. The average test results obtained by students in the first cycle 59 with the percentage of classical $35 \%$ and the second cycle obtained an average of 88 with a percentage of $90 \%$ classics.
\end{abstract}

(C) Muhammadiyah University Palangkaraya

Keywords: learning outcomes, cooperative learning numbered head together (NHT) type.

\begin{abstract}
ABSTRAK
Penelitian ini bertujuan untuk mengetahui aktifitas belajar dan peningkatan hasil belajar peserta didik dikelas XI-8 pada mata pelajaran Ekonomi dengan menggunakan model pembelajaran kooperatif tipe NHT. Metode yang digunakan dalam penelitian ini adalah Penelitian Tindakan Kelas (PTK). Subjek dalam penelitian ini semua peserta didik kelas XI-8 yang berjumlah 37 orang di SMAN 4 Palangka Raya. Teknik pengumpulan data yang diperlukan dalam penelitian ini adalah Observasi, Dokumentasi dan Test. Teknik analisis data yang digunakan adalah kualitatif dan kuantitatif. Hasil penelitian disimpulkan bahwa: (1) Aktivitas belajar peserta didik menjadi lebih aktif. Hal ini dibuktikan dari respon peserta didik terhadap proses pembelajaran yang lebih bersemangat, sehingga dapat dikatakan model pembelajaran Numbered Head Together (NHT) efektif untuk meningkatkan hasil belajar Ekonomi, (2) Ada peningkatan hasil belajar. Hasil rata-rata test yang diperoleh peserta didik pada siklus I 59 dengan persentase klasikal 35\% dan pada siklus II diperoleh rata-rata 88 dengan persentase klasikal 90\%.
\end{abstract}

(C) Universitas Muhammadiyah Palangkaraya

Kata Kunci: hasil belajar, pembelajaran kooperatif tipe numbered head together (NHT). 


\section{PENDAHULUAN}

Pendidikan merupakan upaya yang strategis meningkatkan sumber daya manusia dan upaya mewujudkan cita-cita bangsa Indonesia dalam mewujudkan kesejahteraan umum dan mencerdaskan kehidupan bangsa.

Proses pembelajaran merupakan aktifitas penting, karena melalui proses pembelajaran itulah tujuan pendidikan akan tercapai dalam bentuk perubahan perilaku peserta didik.

Dalam pembelajaran di Sekolah Menengah Atas, Ekonomi merupakan salah satu mata pelajaran yang masih dianggap sulit dipahami oleh peserta didik, sebagian besar peserta didik menganggap pelajaran Ekonomi adalah pelajaran yang membosankan, tidak menarik. Melihat hal ini maka dalam proses pembelajaran Ekonomi diperlukan suatu metode mengajar yang bervariasi, agar peserta didik menganggap pelajaran Ekonomi bukanlah pelajaran yang sulit, membosankan dan tidak menarik lagi sehingga pelajaran Ekonomi menjadi pelajaran yang disenangi oleh peserta didik dan pada akhirnya semangat mereka untuk mengikuti pelajaran Ekonomi tersebut akan membuat hasil belajar mereka akan lebih baik.

Hasil belajar adalah perubahanperubahan yang terjadi pada diri peserta didik yang menyangkut aspek kognitif, apektif dan psikomotorik sebagai hasil kegiatan belajar. Pengertian tentang hasil belajar menurut Susanto, (2013:5) yang menyatakan bahwa hasil belajar dapat diartikan sebagai tingkat keberhasilan siswa dalam mempelajari materi pelajaran di sekolah yang dinyatakan dalam skor yang diperoleh dari hasil tes mengenal sejumlah materi pelajaran tertentu.

Menurut Kunandar (2009:241) mengemukakan bahwa hasil belajar adalah kemampuan peserta didik dalam memenuhi suatu tahapan pencapaian pengalaman belajar dalam suatu kompetensi dasar. Dapat disimpulkan bahwa yang dimaksud dengan hasil belajar adalah yang dicapai oleh peserta didik yang berupa penguasaan pengetahuan dan keterampilan terhadap materi tertentu. hasil belajar dapat dinyatakan dalam bentuk angka, huruf maupun kalimat yang dierikan guru dalam suatu periode tertentu melalui kegiatan belajar.

Belajar juga merupakan tindakan dan prilaku peserta didik yang komplek, sebagai tindakan belajar hanya dialami oleh peserta didik itusendiri. Menurut Sagala (dalam Dimyati dan Mudjino, 2006:13) mengungkapkan belajar sebagai suatu proses dimana suatu organisme berubah prilakunya sebagai akibat dari pengalaman. Sedangkan menurut Aunurrahman (2010:38) menyatakan belajar seringkali diartikan sebagai aktivitas untuk memperoleh pengetahuan,kecakapan, ketrampilan dan sikap. Jadi, belajar ekonomi lebih mengarah kepada proses atau tidakan yang dilakukan peserta didik untuk menambah pengetahuan khusus dalam bidang ekonomi, baik itu secara mikro maupun secara makro ekonomi serta kaitannya dalam kehidupan sehari-hari.

Pembelajaran

Kooperatif merupakan model pembelajaran yang dikembangkan berdasarkan prinsip konstrukfisime dari Vigotski, yang 
menganggap bahwa peserta didik lebih mudah menemukan dan memahami konsep-konsep yang sulit jika mereka saling mendiskusikannya masalah tersebut dengan temannya. Pembelajaran kooperatif mengacu pada metode pengajaran dimana peserta didik bekerjasama dengan kelompok kecil yang saling membantu dalam belajar.

Trianto (2009:13) mengatakan bahwa proses pembelajaran secara kooperatif adalah suatu model pembelajaran yang menjadikan peserta didik sebagai subjek belajar sehingga dapat meningkatkan partisifasi peserta didik, memfasilitasi peserta didik dengan pengalaman serta memberikan kesempatan kepada peserta didik untuk berinteraksi dan belajar secara bersama. Sedangkan Anita Lie (2008: 29) mengungkapkan bahwa model pembelajaran cooperative learning tidak sama dengan sekedar belajar dalam kelompok. Ada lima unsur dasar pembelajaran cooperative learning yang membedakannya dengan pembagian kelompok yang dilakukan asal-asalan. Pelaksanaan model pembelajaran kooperatif dengan benar akan menunjukkan pendidik mengelola kelas lebih efektif. Pembelajaran kooperatif menekankan pada kehadiran teman sebaya yang berinteraksi dengan sesama sebagai sebuah tim dalam menyelasaikan dan membahas suatu masalah.

Berdasarkan hasil observasi yang dilakukan di SMA Negeri 4 Palangka Raya salah satu penguasaan meteri Ekonomi yang tergolong rendah yaitu pada materi Akuntansi, dimana pada materi tersebut banyak peserta didik yang belum bisa pelajaran akuntansi, penjurnalan. Pada materi ini 21 dari 37 peserta didik belum bisa mendapatkan nilai yang memuaskan dari hasil tugas. Sedangkan Nilai Ketuntasan Minimal (KKM) 7,50. Jumlah dan peserta didik kelas XI-8 SMA Negeri 4 Palangka Raya 37 peserta didik, yang mampu memenuhi perolehan nilai standar 16 (43\%)peserta didik sedangkan $21(57 \%)$ peserta didiknya belum memenuhi nilai standar atau di bawah KKM. Berdasarkan proses pembelajaran yang dilaksanakan dan hasil nilai ulangan harian peserta didik.

Alasan menggunakan metode pembelajaran kooperatip tipe Numbered Head Together (NHT) adalah untuk mengatasi masalah hasil belajar Ekonomi pada peserta didik kelas XI-8 SMAN Palangka Raya. metode pemelajaran kooperatif tipe Numbered Head Together (NHT) adalah sa;ah satu tipe kooperatif yang menekankan pada adanya aktifitas dan interaksi diantara peserta didik untuk saling memotivasi dan saling membantu dalam menguasai materi pelajaran guna mencapai prestasi yang maksimal.

\section{METODE PENELITIAN}

Metode yang digunakan dalam penelitian ini adalah Penelitian kualitatif dan kuantitatifdengan pendekatan penelitian Tindakan Kelas (PTK).Menurut Kurt Lewin,( Kunandar, 2009:60) Penelitian Tindakan Kelas merupakan suatu rangkaian langkah yang terdiri atas empat tahap, yakni perencanaan, tindakan, pengamatan, dan refleksi. 
Penelitian Tindakan Kelas (PTK) dilaksanakan dalam 2 siklus. Menurut Arikunto, dkk (2008:20) bahwa ada 4 tahapan penting dalam penelitian tindakan yaitu perencanaan, pelaksanaan, observasi dan refleksi.

Adapun subjek dalam penelitian ini semua peserta didik kelas XI-8 yang berjumlah 37 orang di SMA Negeri 4 Palangka Raya. Semua peserta didik ikut berpartisipasi dalam penelitian ini sehingga data yang diperoleh peneliti dapat bener-bener merupakan data yang dapat mewakili dari kendala yang dihadapi peserta didik kelas XI-8 dalam menyelesaikan soal Ekonomi.

\section{HASIL PEMBAHASAN}

Aktivitas belajar Ekonomi peserta didik lebih aktif dengan menggunakan model pembelajaran Numbered Head Together (NHT) pada peserta didik kelas XI-8 SMAN 4 Palangka Raya. Hal ini dibuktikan dari respon peserta didik terhadap proses pembelajaran yang lebih bersemangat, sehingga dapat dikatakan model pembelajaran Numbered Head Together (NHT) efektif untuk meningkatkan hasil belajar Ekonomi. Dapat dilihat dari hasil pengamatan aktifitas peserta didik pada siklus I dan siklus II.

Ada peningkatan hasil belajar Ekonomi dengan menggunakan model pembelajaran Numbered Head Together (NHT) pada peserta didik kelas XI-8 SMAN 4 Palangka Raya. Hal ini dibuktikan dari peningkatan hasil belajar Ekonomi pada pre test dengan nilai 39 termasuk kriteria sangat kurang tercapai, suklus I dengan nilai 59 termasuk kriteria kurang tercapai, sedangkan pada siklus II dengan nilai 88 termasuk kriteria sangat tercapai. Rumus klasikal ketuntasan proses pembelajaran sebasar $85 \%$. Menerapkan model pembelajaran yang aktif dan kreatif diharapkan dapat meningkatkan aktivitas belajar peserta didik. Selain menciptakan proses pembelajaran menjadi lebih menarik yaitu proses pembelajaran dilakukan secara kelompok.

Dengan demikian model pembelajaran tipe Numbered Hear Together (NHT) memiliki dampak positif yang sangat signifikan terhadap peningkatan hasil belajar Ekonomi pada peserta didik kelas XI-8 SMAN-4 Palangka Raya.

\section{DAFTAR PUSTAKA}

Arikunto, Suharsimi. 2008. Penelitian Tindakan Kelas, Jakarta: Bumi Aksara

Aunurahman. 2010. Belajar dan Pembelajaran, Bandung: Alfabeta

Dimyati dan Mudjiono. 2006. Belajar dan Pembelajaran. Jakarta: Rineka Cipta.

Kunandar. 2009. Guru Profesional. Jakarta: Rajawali Pers.

Lie, A. 2008. Mempraktikan Cooperative Learning di Ruang Kelas. Jakarta : Gramedia

Susanto, Ahmad. 2013. Teori Belajar Dan Pembelajaran Di Sekolah Dasar. Jakarta: PT. Fajar Interpratama Mandiri.

Trianto. 2009. Mendesain Pembelajaran Inovatif Progresif, Jakarta : Prestasi Pustaka. 